\title{
A Case of Erdheim-Chester Disease with Laryngeal Involvement
}

\author{
Jin Su Park, Myung-Gi Moon, Jae Hyuk Lee, and Sang Hyuk Lee \\ Department of Otorhinolaryngology-Head and Neck Surgery, Kangbuk Samsung Hospital, \\ Sungkyunkwan University School of Medicine, Seoul, Korea
}

\section{후두 침범을 동반한 Erdheim-Chester 병 1예}

박진수 · 문명기 · 이재혁 · 이상혁

성균관대학교 의과대학 강북삼성병원 이비인후과학교실

\author{
Received November 27, 2015 \\ Revised January 17,2016 \\ Accepted January 20, 2016 \\ Address for correspondence \\ Sang Hyuk Lee, MD \\ Department of Otorhinolaryngology- \\ Head and Neck Surgery, \\ Kangbuk Samsung Hospital, \\ Sungkyunkwan University \\ School of Medicine, \\ 29 Saemunan-ro, Jongno-gu, \\ Seoul 03181, Korea \\ Tel $+82-2-2001-2269$ \\ Fax $+82-2-2001-2273$ \\ E-mailentlsh@hanmail.net
}

Erdheim-Chester disease (ECD) is a rare form of non-Langerhans cell histiocytosis with multi-organ involvement. Bones, cardiovascular system, central nervous system, kidney, skin and many different organs can be involved but laryngeal involvement has not been reported in literatures. The diagnosis of ECD was based on clinical manifestations and immunohistochemical findings including CD68(+), CD1a(-) and S100(-). Currently, Interferon-a is the most extensively studied agent in the treatment of ECD and serves as the 1st line of treatment. Surgical resection of involved lesions can be tried but it leads to temporary improvement. A 60 -year-old man visited with respiratory symptoms because of ECD with laryngeal involvement. We resected the obstructive lesion to relieve the symptoms. Tissue biopsy gave a diagnosis of ECD. As it is rare to encounter ECD involving the larynx, we report this case with a review of literatures. Korean J Otorhinolaryngol-Head Neck Surg 2016;59(10):738-41

Key Words Epiglottis · Erdheim-Chester disease · Larynx · Non-Langerhans cell histiocytosis.

\section{서 론}

Erdheim-Chester disease(ECD)는 1930년 Jakob Erdheim과 William Chester에 의해 처음 기술된 다발성 장기를 침범하는 비 랑게르한스 세포 조직구증이다. ${ }^{1)}$ 전 세계적으로 약 600예가 보고되어 있는 드문 질환으로 40 70대에 호발하 며 남성(73\%)에서 비교적 많은 수로 나타나는 것으로 보고되 어 있다. ${ }^{2}$ 근골격계, 심혈관계, 중추신경계, 신장 및 피부 등을 침범하여 다양한 임상 양상을 나타내며, 특히 중추신경계와 심혈관계 침범 시 더 예후가 좋지 않다고 알려져 있다. 전신의 다양한 장기에 침범이 가능한 것으로 알려져 있으나 지금까지 의 문헌에서는 후두를 침범한 $\mathrm{ECD}$ 는 아직 보고되지 않았다.

$\mathrm{ECD}$ 의 병인은 명확하게 밝혀지지 않았으나 최근 연구에 의하면 V600E BRAF mutation과 관련이 있는 것으로 알려
져 있다. ${ }^{3)} \mathrm{ECD}$ 에서 V600E BRAF mutation의 빈도는 일반적 으로 $38 \%$ 에서 $68 \%$ 정도로 알려져 있으며 최근에 보고된 한 연구에서는 $100 \%(18 / 18)$ 까지도 보고되었다. ${ }^{4-8)}$

$\mathrm{ECD}$ 는 영상의학적 검사와 면역조직학적 소견을 바탕으로 진단할 수 있다. $\mathrm{ECD}$ 는 하지의 장골에 가장 흔하게 침범하는 것으로 알려져 있어, 이에 대한 영상의학적 검사로 X-ray에서 양측성의 대칭적인 골경화성 병변이 나타나며, $99 \mathrm{mTc}$ bone scintigraphy에서는 장골의 원 위부 골 간단부의 비정상적으 로 강한 섭취의 형태가 관찰된다. 또한 이외에 침범한 것으로 예상되는 병변에 대하여 전산화단층촬영, 자기공명영상, 양 전자컴퓨터단층촬영(PET-CT) 등을 이용해 진단에 도움을 받을 수 있다. 하지만 영상 검사를 통해 진단에 도움을 받을 수 있으나 그 진단에 필수적인 조건은 아니다.

$\mathrm{ECD}$ 의 확정 진단은 조직학적 검사를 통해 이루어진다. 침 
범한 것으로 의심되는 병변의 조직검사에서 전형적인 $\mathrm{ECD}$ 의 조직구들을 관찰할 수 있는데, Birbeck 과립이 관찰되지 않 는 비 랑게르한스 세포 거품 조직구증을 보이며, polymorphic granuloma and fibrosis, xanthogranulomatosis, fibroblast proliferation, lymphocytic aggregates, Touton giant cells 등 이 관찰된다. 또한 면역조직화학염색에서 $\mathrm{CD} 68(+), \mathrm{CDla}(-)$, S-100(-) 소견을 보인다.9) 이 외에도 다양한 현미경적, 초미세 구조, 면역조직화학적 특징들을 보이는 것으로 알려져 있다.

지금까지 $\mathrm{ECD}$ 의 관해, 조절을 위한 다양한 치료들이 시도 되었으나 아직까지는 경험적 치료에 의존하고 있으며 완치 가 능한 치료법은 아직까지 나타나지 않았다. 현재는 1 차 약제로 interferon-a, peginterferon-a가 쓰이고 있으며 이에 반응이 없는 경우, 2차 약제로 cladribine, vemurafenib, anakinra 등 이 사용되고 있으나 이러한 약제들은 빠르고 확실한 치료를 기대하기 어려우며 장기간 사용하여야 하기 때문에 치료에 어려움이 있다. ${ }^{10-13)}$ 또한 침범한 병변에 따라 수술적 절제도 고려해 볼 수 있으나 일시적인 효과를 보일 뿐이며 근본적인 치료에는 한계가 있다. ${ }^{3)}$

저자들은 60 세 남자 환자에서 후두 침범을 동반한 $\mathrm{ECD}$ 를 경험하였기에 문헌 고찰과 함께 보고하고자 한다.

\section{증 례}

60세 남자 환자가 2달 전부터 발생한 호흡곤란을 주소로 내원하였다. 환자는 호흡 시 불편감, 삼킴 시 이물감 및 경미 한 음성 변화를 호소하고 있었으나 혈액 검사에서 산소 포화 도 저하 및 저산소혈증의 소견은 나타나지 않았다. 신체 진 찰에서는 비강 내에 특이 소견은 관찰되지 않았으며, 양측 눈, 코, 입술 주위와 목, 양쪽 겨드랑이, 사타구니 및 구강 내 점막에 황갈색의 다발성 구진성 병변이 관찰되었다(Fig. 1).

후두내시경검사에서 양측 피열연골, 피열후두개주름, 후두 개 및 하인두 점막의 다발성의 황색 결절성 병변이 관찰되었 다. 특히 후두개 상부에서는 $2 \mathrm{~cm}$ 크기의 비교적 큰 병변이 관찰되었으며, 이 병변이 기도를 막고 있어 환자의 증상을 일 으키는 것으로 예상되었다(Fig. 2). 황색 결절성 병변은 가 성 대 및 진 성대의 점막에서는 관찰되지 않았으며 성대의 움직 임에는 이상이 없었다. 후두 내시경검사에서 관찰되는 점막 의 병변은 심부의 침범이 없이 점막하층에 국한되어 있는 것 으로 보여져 영상의학적 검사는 시행하지 않았다.

지방종, 황색종, 기타 전신성 질환 등을 의심하여 정확한 진단과 환자의 증상 해결을 위해 후두내시경검사에서 관찰 된 후두개 상부의 $2 \mathrm{~cm}$ 크기의 결절성 병변에 대하여 수술 적 절제를 계획하였다. 전신마취 하에 현수후두경을 이용하
여 후두개의 결절성 병변을 노출 시키고 $400 \mathrm{~mm}$ 렌즈를 부 착한 수술용 현미경으로 병변의 경계를 확인하였다. Sharplan $\mathrm{CO}_{2}$ laser with acupot 712 Microslad(microscope laser adapter device, ESC/Sharplan, Israel)를 5 watt의 세기와 super pulse mode로 맞춘 후 병변의 경계를 확인하며 조심 스럽게 박리를 하였다. 병변은 주변 조직에 유착 없이 비교적 쉽게 절제되었으며 출혈이나 심한 후두개 부종은 발생하지 않았다. 수술 후 3일째 별다른 합병증 없이 퇴원하였고 외래 추적관찰 하였다. 수술 후 시행한 조직검사에서 $\mathrm{H \& E}$ 염색 에서 림프구, 포말 조직구 등의 침윤이 관찰되었으며 면역조 직화학 염색에서 $\mathrm{CD} 68(+), \mathrm{CD1a}(-), \mathrm{S}-100(-)$ 소견을 보이는 비 랑게르한스 세포 조직구증을 보였다(Fig. 3).

또한 환자의 피부 병변에 대하여 시행한 조직검사에서도 비 랑게르한스 세포 조직구증 및 CD68(+), CDla(-), S-100(-) 등 을 나타내어 후두개의 병변에서 시행한 조직검사와 일치하는 소견을 보이고 있었다.

환자는 3년 전부터 고혈압으로 약물 치료 중이었으며, 2년 전부터 $68 \mathrm{~kg}$ 에서 $57 \mathrm{~kg}$ 으로 $11 \mathrm{~kg}$ 의 체중 감소 및 경미한 전신 쇠약감을 보였다. 또한, 환자는 1 년전부터 좌측 다리의 만성적 통증을 호소하고 있었다. 다리의 병변에 대한 진단을 위해 X-ray 및 $99 \mathrm{mTc}$ bone scintigraphy를 시행하였으나 특이 소견은 관찰되지 않았다. 혈액검사에서는 AST $83 \mathrm{IU} / \mathrm{L}$, ALT 71 IU/L, Serum creatinine $2.1 \mathrm{mg} / \mathrm{dL}$, BUN $21.0 \mathrm{mg} /$ $\mathrm{dL}$ 로 간, 신기능 저하를 보였다. 이에 대해 복부전산화단층촬 영을 시행하였으나 간과 신장에 대한 침범 소견은 관찰되지 않았다.

환자의 후두개 및 피부 병변에서 시행한 조직검사에서 비 랑게르한스 세포 조직구증, $\mathrm{CD} 68(+), \mathrm{CDla}(-), \mathrm{S}-100(-)$ 소견을 보인 점, 이 외에 다리의 만성적 통증, 간 기능 저하, 신 기능 저 하 등의 임상 양상을 고려할 때 Erdheim-Chester 병을 진단 할 수 있었다. 수술적 치료 시행 후 내과적으로 interferon-a 를 투여하였으며, 2주, 1 개월째 외래 내원하였으며 환자는 호 흡곤란, 삼킴 곤란 등의 증상을 호소하지 않았고 후두내시경 검사 상 합병증 및 재발 소견은 관찰되지 않았다. 수술 6개 월 후, 후두내시경검사에서 결절성 병변의 진행은 관찰되지 않았으며 호흡곤란 등의 증상 또한 호소하지 않았다(Fig. 2).

\section{고 찰}

$\mathrm{ECD}$ 는 다발성 장기를 침범하는 비 랑게르한스 세포 조직 구증이다. ${ }^{1)}$ 근골격계, 심혈관계, 중추신경계, 신장 및 피부 등 에 침범이 가능하며 침범한 장기에 따라서 다양한 임상 양상 및 예후를 보일 수 있다. ${ }^{14)}$ 특히, 중추신경계의 침범, 폐 침윤, 

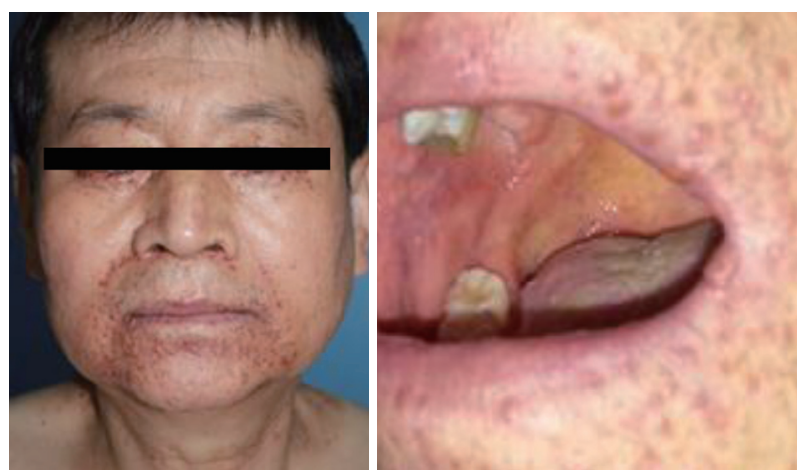

Fig. 1. In physical examination, diffuse yellowish papules, cutaneous involvement of periocular, perioral and oral mucosal lesions were visible.
흥막 침윤으로 인한 진행성 호흡곤란, 심혈관계 침범으로 인 한 심낭압전, 후복막 및 신장 침범으로 인한 신부전, 패혈증 등이 발생할 때 예후가 더욱 좋지 않은 것으로 알려져 있다. 지금까지의 연구에 따르면, 32 개월간 경과 관찰한 연구에서 생존율은 $43 \%$ 정도였으며, ${ }^{15)}$ 적절한 치료를 받은 경우 1 년 생존율이 96\%, 5년 생존율이 68\%로 보고되었다. ${ }^{10)}$ 40 60대 에 특히 남성에서 다소 호발하는 것으로 알려져 있으며, 전 세 계적으로 약 600예가 보고되어 있는 드문 질환으로 대부분 의 경우가 최근 10 년 동안 보고되었다. 하지만 후두에 $\mathrm{ECD}$ 가 발생한 경우는 아직까지 문헌에 보고되지 않았다. ${ }^{2}$

본 증례에서는 황색 구진성 병변이 전신에 걸쳐 침범하였
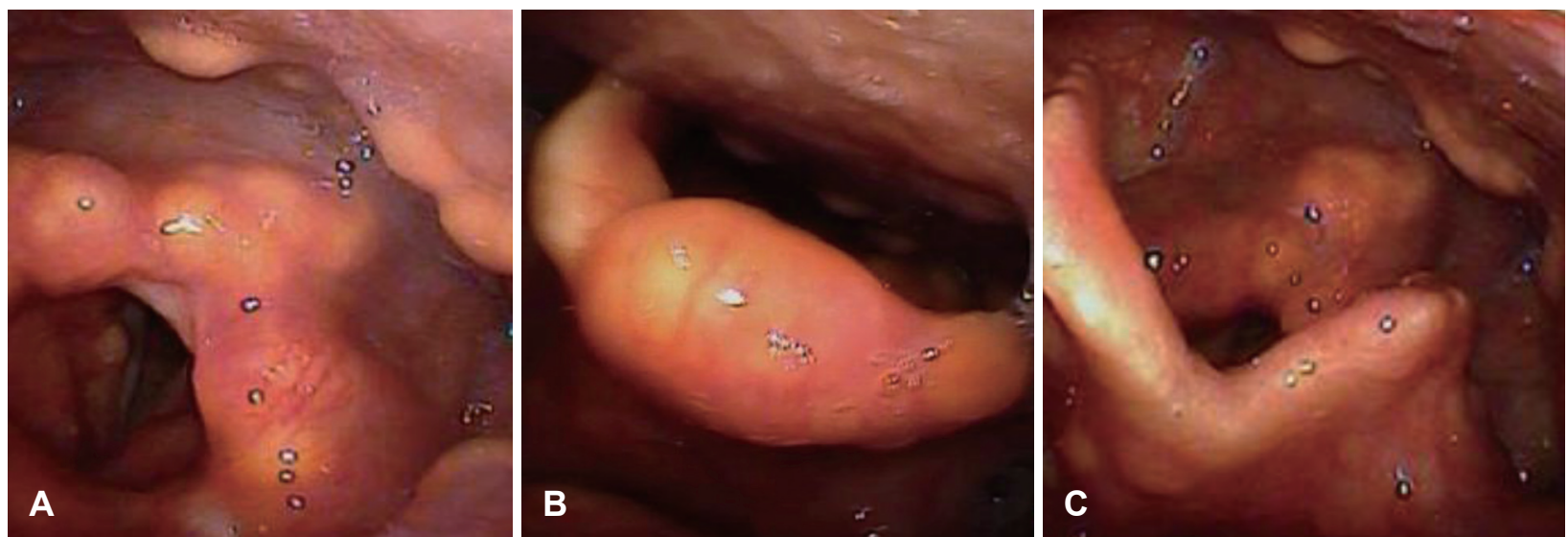

Fig. 2. Multiple yellowish nodular lesion on arytenoid, aryepiglottic fold, and hypopharynx (A), $2 \mathrm{~cm}$ sized nodular mass on upper portion of epiglottis (B) were observed in flexible laryngoscopic findings. In post-operatively 6 months, complete healing state without complications (C) was visible.

Fig. 3. In histopathologic findings, H\&E stains $(A) \times 100$, a mixture of lymphocytes, histiocytes, foamy cells, and giant cells were observed in microscopy. Immunohistochemical stains showed positive for CD68 in histiocytes and giant cells, $\times 100$ (B), negative for CD1a, $\times 100$ (C) and negative for $\mathrm{S} 100, \times 100$ (D).
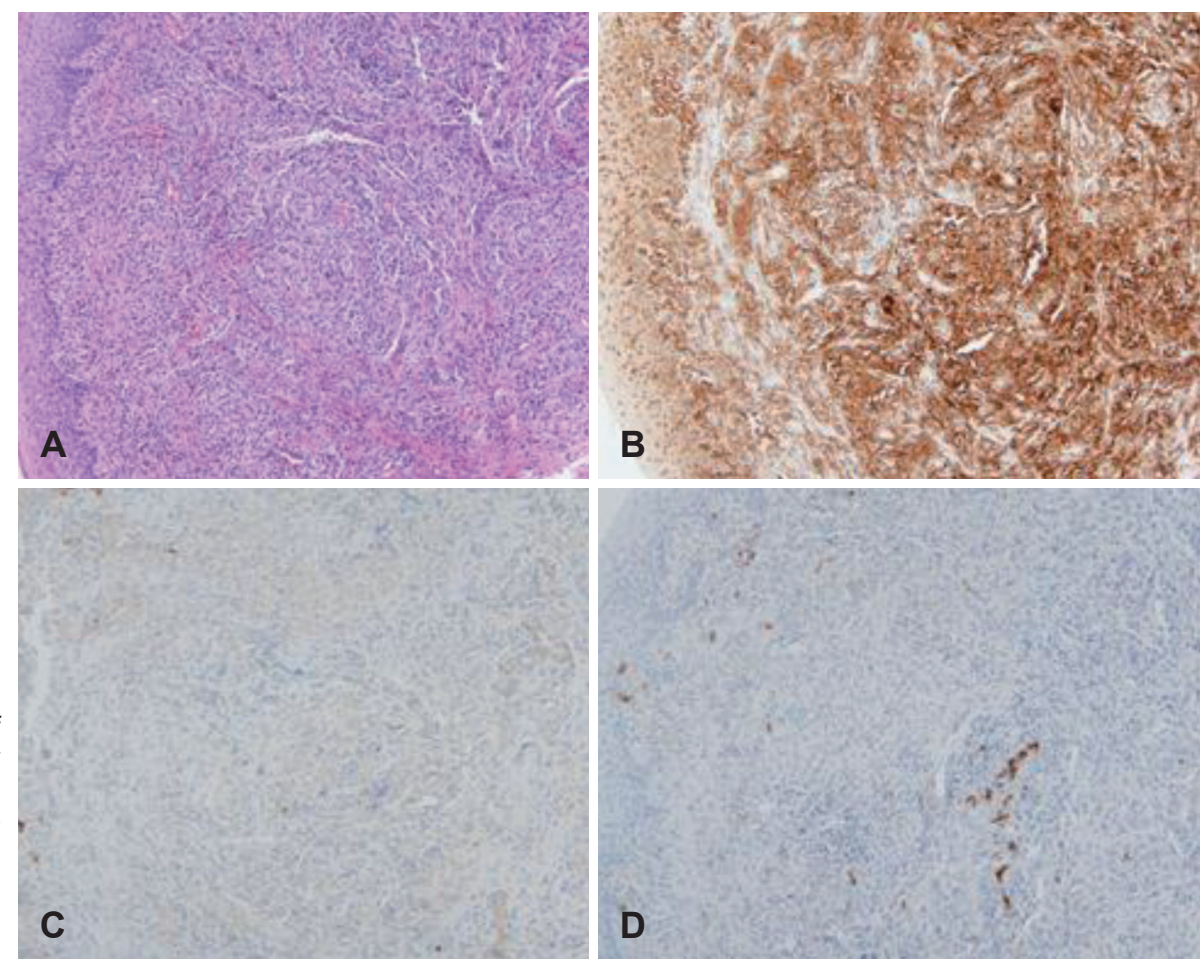
고 구강 점막과 후두개 및 후두의 점막을 침범하였다. 특히 후두개 상부에서 $2 \mathrm{~cm}$ 크기의 결절성 종괴가 관찰되었고 이 로 인해 호흡곤란 및 삼킴 곤란 등의 증상이 나타나는 것으 로 생각되었다. 이와 같이 기도 폐색 증상을 일으키는 경우, 혹은 기도 폐색이 예상되는 경우 크기 변화 및 증상에 대한 주의 깊은 경과 관찰이 필요하며 전신적인 치료 여부와 상관 없이 수술적 절제가 필요할 것으로 생각된다. 본 증례에서는 병변에 대한 수술적 절제를 시행하였고, 이후 외래 경과 관 찰 시행하였다. 외래 경과 관찰 기간 중, 증상 및 병변의 재발 소견은 관찰되지 않았으며 병변의 진행은 관찰되지 않았다. 하지만 수술적 치료는 일시적 증상 해결로 완치를 기대하기 어렵고 병변의 재발 가능성 및 기도 폐색의 가능성이 있으 므로 정기적인 경과 관찰이 필요할 것으로 보인다. 또한 전신 마취 하에 경구강적 접근이 어려운 경우, 기도의 과도한 폐 색으로 수술적 절제가 어려운 경우에는 기관절개술을 통해 기도확보를 고려해야 할 것으로 생각된다.

수술 후 시행한 조직검사에서 $\mathrm{H} \& \mathrm{E}$ 염색에서 림프구, 포 말 조직구 등의 침윤이 관찰되었으며 CD68(+), CD1a(-), S-100(-) 소견을 보였고 또한 피부에서 시행한 조직검사에서 동일한 결과를 나타내어 $\mathrm{ECD}$ 를 의심할 수 있었다. 환자는 후두개 및 피부의 병변 이외에도 좌측 다리의 만성적인 통증 을 호소하고 있었으며 혈액 검사에서 간, 신 기능의 저하 소 견을 보여 다리와 간, 신장의 침범이 의심되었다. 하지만 이에 대해 시행하였던 영상의학적 검사들에서 특이적인 소견은 나타나지 않았다. 이는 초기 병변으로 영상 검사에 병변이 아직 나타나지 않았을 가능성에 대해 생각해 볼 수 있었다. 정확한 진단을 위해 MRI 및 PET-CT 등의 추가 검사를 시 행해 볼 수 있으며 의심되는 병변들에 대해 정기적인 추적 관찰이 필요할 것으로 생각된다.

$\mathrm{ECD}$ 는 매우 드문 질환으로 아직까지 진단과 치료에 많은 어려움이 있다. 현재까지의 치료로는 완치의 개념보다 삶의 연 장과 삶의 질을 높여주는 데에 목적이 있다. 또한 이비인후과 의 영역에서의 $\mathrm{ECD}$ 는 아직까지 보고된 적이 없었다. 이와 같 은 드문 질환을 마주칠 때, 이비인후과의 영역에 생긴 병변에 대하여 전신 질환의 가능성에 대하여 생각해보고 다각도에서
접근하여 진단 및 치료를 고려해야 할 것이다.

\section{REFERENCES}

1) Chester W. Über Lipoidgranulomatose. Virchows Arch Pathol Anat Physiol Klin Med 1930;279:561-602.

2) Diamond EL, Dagna L. Hyman DM, Cavalli G, Janku F, Estrada-Veras $\mathrm{J}$, et al. Consensus guidelines for the diagnosis and clinical management of Erdheim-Chester disease. Blood 2014;124(4):483-92.

3) Mazor RD, Manevich-Mazor M, Shoenfeld Y. Erdheim-Chester Disease: a comprehensive review of the literature. Orphanet J Rare Dis 2013;8:137.

4) Badalian-Very G, Vergilio JA, Degar BA, MacConaill LE, Brandner $\mathrm{B}$, Calicchio ML, et al. Recurrent BRAF mutations in Langerhans cell histiocytosis. Blood 2010;116(11):1919-23.

5) Arnaud L, Bach G, Zeitoun D, Drier A, Cluzel P, Grenier PA, et al. Whole-body MRI in Erdheim-Chester disease. Rheumatology (Oxford) 2012;51(5):948-50.

6) Satoh T, Smith A, Sarde A, Lu HC, Mian S, Trouillet C, et al. B-RAF mutant alleles associated with Langerhans cell histiocytosis, a granulomatous pediatric disease. PLoS One 2012;7(4):e33891.

7) Sahm F, Capper D, Preusser M, Meyer J, Stenzinger A, Lasitschka F, et al. BRAFV600E mutant protein is expressed in cells of variable maturation in Langerhans cell histiocytosis. Blood 2012;120(12):e28-34.

8) Cangi MG, Biavasco R, Cavalli G, Grassini G, Dal-Cin E, Campochiaro $\mathrm{C}$, et al. BRAFV600E-mutation is invariably present and associated to oncogene-induced senescence in Erdheim-Chester disease. Ann Rheum Dis 2015;74(8):1596-602.

9) Arnaud L, Pierre I, Beigelman-Aubry C, Capron F, Brun AL, Rigolet A, et al. Pulmonary involvement in Erdheim-Chester disease: a singlecenter study of thirty-four patients and a review of the literature. Arthritis Rheum 2010;62(11):3504-12.

10) Arnaud L, Hervier B, Néel A, Hamidou MA, Kahn JE, Wechsler B, et al. CNS involvement and treatment with interferon- $\alpha$ are independent prognostic factors in Erdheim-Chester disease: a multicenter survival analysis of 53 patients. Blood 2011;117(10):2778-82.

11) Haroche J, Amoura Z, Trad SG, Wechsler B, Cluzel P, Grenier PA, et al. Variability in the efficacy of interferon-alpha in Erdheim-Chester disease by patient and site of involvement: results in eight patients. Arthritis Rheum 2006;54(10):3330-6.

12) Braiteh F, Boxrud C, Esmaeli B, Kurzrock R. Successful treatment of Erdheim-Chester disease, a non-Langerhans-cell histiocytosis, with interferon-alpha. Blood 2005;106(9):2992-4.

13) Suzuki HI, Hosoya N, Miyagawa K, Ota S, Nakashima H, Makita $\mathrm{N}$, et al. Erdheim-Chester disease: multisystem involvement and management with interferon-alpha. Leuk Res 2010;34(1):e21-4.

14) Carpinteri R, Patelli I, Casanueva FF, Giustina A. Pituitary tumours: inflammatory and granulomatous expansive lesions of the pituitary. Best Pract Res Clin Endocrinol Metab 2009;23(5):639-50.

15) Veyssier-Belot $C$, Cacoub P, Caparros-Lefebvre D, Wechsler J, Brun B, Remy M, et al. Erdheim-Chester disease. Clinical and radiologic characteristics of 59 cases. Medicine (Baltimore) 1996;75(3):157-69. 